\title{
Wessendorf, Susanne (2020): Ethnic minorities' reactions to newcomers in East London: symbolic boundaries and convivial labour
}

The British Journal of Sociology, DOI: 10.1111/1468-4446.12729

\begin{abstract}
In much public discourse on immigrants in Western Europe, perceptions towards newcomers are discussed in relation to what white national majorities think. However, today, new migrants often move into places which are already settled by previous migrants. This article investigates the local experiences, perceptions and attitudes towards newcomers among long-established ethnic minorities in an area which they have made their home, and where they predominate not just in numbers but also by way of shops, religious sites, school population, etc. Based on ethnographic fieldwork in East London (UK), it looks at long-established ethnic minority residents' attitudes towards newcomers from Eastern Europe, and how these are shaped by their own histories of exclusion. By bringing together theories on symbolic boundary making with the concept of 'convivial labour' (Nobel 2009; Wise 2016), it shows how experiences of stigmatization impact on perceptions of white newcomers, and how these perceptions are characterized by a combination of empathy and resentment.
\end{abstract}

Keywords: Conviviality, symbolic boundaries, migration, East London

At a secondary school in the London Borough of Newham, the biggest insult the students can give to others is 'freshie'. 'Freshie' refers to newcomers, people who are 'fresh off the boat', speak poor English or have a funny accent, dress differently, and are unfamiliar with the local codes of behaviour (Charsley \& Bolognani, 2017). Newham has seen large numbers of immigrants since the 
1950s and 60s. The youth at the secondary school are not of white British backgrounds, but of various different origins. Having been born in the area, they feel a strong sense of belonging to the area, especially in light of dramatic changes in recent years relating to the immigration of newcomers from many different parts of the world. Eastern European migrants represent not only one of the biggest newcomer groups in terms of numbers, but also in terms of perceptions of population changes among long-term residents. Since EU Accession, the population of Eastern Europeans in the borough has gone up to 8\% (Aston-Mansfield, 2017), and their presence is visible by way of local businesses, in schools and in public space.

New migrants often move into places which are already settled by previous migrants. Such areas are frequently used as 'arrival zones' where newcomers find their feet (Pemberton \& Phillimore, 2016; Phillimore, et al. 2014). While in much public and policy discourse, the assumption prevails that it is white majority residents who have to contend with the changes which immigration can bring to an area, an emerging body of research in the UK and beyond has looked at the local experiences, perceptions and attitudes towards newcomers among long-established ethnic minorities in areas which they have made their home, and where they predominate not just in numbers but also by way of shops, religious sites, school population, etc. (Albeda et al. 2018; Erel 2011; Hall 2012; Heil 2014; Hickman, Mai \& Crowley 2012; Phillips et al. 2014).

This article pushes this body of literature further by bringing together literature on conviviality with theories on symbolic boundary making. The article aims to advance scholarship on inclusion and exclusion in contexts of urban diversity by examining how ethnic minorities in the London Borough of Newham react to white newcomers. More specifically, it examines how longterm experiences of racism and Islamophobia impact on their perceptions of new, white migrants from Eastern Europe who are sometimes 'othered' themselves (Cole 2009; Fox, et al. 2012), but whose children are more likely to become accepted as part of the national majority. It asks how long-established residents' attitudes towards newcomers are shaped by a combination of their own histories of racism and exclusion, as well as convivial social practices in everyday life. 
The following section discusses the relevant literature on symbolic boundary making and urban conviviality, drawing on Noble's (2009) and Wise's (2016) work on 'convivial labour', which is a useful concept to describe efforts to cross symbolic boundaries. This will be followed by an introduction to the London Borough of Newham where the research takes place.

The empirical part of the article first focuses on experiences of racism among longestablished ethnic minorities. It draws out three types of symbolic boundaries which repeatedly came up in accounts and observations of racism during the fieldwork: one relates to notions of 'the other' (e.g. Muslims) taking over the area. The second theme relates to language, and the third to the idea that ethnic minorities and newcomers do not want to mix. The article uses the notion of convivial labour to illustrate how engaging in convivial labour isa way in which some of the research participants confront racism and deal with stigmatization, while others see a response as pointless.

The second part of the empirical section situates reactions to newcomers within longestablished ethnic minorities' histories of exclusion. It shows how ethnic minorities construct similar symbolic boundaries towards newcomers as those which they were exposed to themselves, namely along notions of territorial 'take over', newcomers not speaking enough English and not wanting to mix. These sentiments are underlined by fear that the newcomers' 'whiteness' facilitates their access to jobs, jeopardizing their own or their children's opportunities. At the same time, however, discourses about newcomers are highly nuanced and research participants situated these within their own histories of immigration and exclusion. While Eastern European migrants' alleged white privileges were portrayed as undoubtable advantage, there was also attentiveness to the challenges faced by these newcomers in the context of Brexit, and new forms of solidarity were expressed in light of newcomers' struggles to settle in the context of a hostile, post-Brexit-vote environment.

\section{Conviviality and symbolic boundaries in contexts of ongoing immigration}

European societies have seen processes of diversification as a result of immigration for many decades, particularly since World War II. From the 1950s until the 1980s, migration to Europe was 
mainly comprised of large numbers of people moving from specific countries to particular places, for example from Turkey to Germany and the Netherlands, Algeria to France, and from South Asia and the Caribbean to the UK. Since the 1980s, more people have been arriving from more countries of origin, and settling in additional countries. Thus, 'old immigration countries' have seen the arrival of more recent migrants from various countries of origin and a range of religious, socio-economic and educational backgrounds, including many different legal statuses (Vertovec, 2007; 2015). An important part of this diversification is the immigration of migrants into urban areas which until today are host to previous migrants. Such more established populations are for example represented by ethnic minorities from South Asia and the Caribbean who came to the UK after the Second World War. They have now been settled for three generations, and they have experienced various degrees of upward social mobility, ongoing immigration due to family reunion, and residential dispersal (Butler \&Hamnett, 2011; Charsley and Bolognani 2017). However, residential concentrations of these ethnic minorities continue to exist, especially in more disadvantaged areas.

A wide range of social scientific literature has addressed the nature of social relations and cohabitation in contexts of immigration-related diversification, which, more recently, has evolved into a burgeoning body of literature on conviviality. Especially since the 'multiculturalism backlash' (Vertovec \& Wessendorf, 2010) in various European countries, and political agendas focusing on 'social cohesion', 'inter-group relations' and 'bridging activities' between different 'ethnic groups', there have been a number of studies looking at social relations between ethnic minority and majority groups on the local level (Blokland, 2003; Dench, Gavron, \& Young, 2006; Hewitt, 2005; Ray, Hudson, \& Phillips, 2008; Phillips et al., 2014). These studies showed that more recent migrants often settle in poorer urban areas (Robinson \& Reeve, 2006) and that settled minority groups can feel a sense of ownership over their area and resentment towards new migrants (Hickman, Mai \& Crowley 2012). A range of recent research has shown how people of different backgrounds living in 'super-diverse' (Vertovec, 2007) urban neighbourhoods 'routinely and peacefully manage social interactions and relations in multicultural environments' (Neal, et al., 2013:309), representing a 
counter-narrative to the political discourse which emphasizes social disintegration, ghettoization and isolation (Amin, 2005; Hall 2012; Noble, 2009; Sandercock, 2003; Wessendorf 2014). Importantly they have shown that different forms of social order can operate in the same context, and patterns of cohabitation can co-exist with racism and xenophobia (Karner \& Parker, 2011; Lee, 2002; Noble, 2011; Tyler, 2016; Valentine, 2013; Wessendorf 2013; 2014; Wise \& Velayutham 2014).

These studies form the background of work on conviviality, much of which draws on Gilroy's definition of conviviality as a 'social pattern in which different metropolitan groups dwell in close proximity but where their racial, linguistic and religious particularities do not - as the logic of ethnic absolutism suggests they must - add up to discontinuities of experience or insuperable problems of communication' (Gilroy, 2004:27). Although often criticised for underlining positive social relations, literature on conviviality has shown the co-existence of both conflictual as well more harmonious social relations in diverse contexts (Wise \& Noble, 2016). Importantly, Wise and Noble (2016:426) emphasise the need to not only look at practices of exclusion, but also of inclusion, stating that 'we need to think about what it is people do when they build connections, just as we need to investigate what people do when they build lines of exclusion'.

Noble develops the idea of 'pragmatic being together' where practices of co-existence are put in the centre of our analysis (Noble, 2009:50). He shows how negotiations of differences in daily life involve 'labour', a phenomenon he describes as the 'labour of intercultural connection' (ibid.:62) which goes beyond the simple practice of living together because it produces affinity. Wise expands on this notion in her work on 'convivial labour' where she describes how 'the everyday practice of living together takes work', it is about negotiating differences in everyday life (2016:496). In Newham, I have found plenty of instances of what could also be described as 'easy conviviality', people getting along across differences, for example by way of neighborly relations and helping each other out in public space. Convivial labour, in contrast, refers to more conscious efforts to get along. It can include convivial practices such as sharing food and other forms of reciprocity, for instance between neighbours or parents at schools (Neal, Vincent \& Iqbal 2016; Noble, 2009; Wise, 2009). As 
I will show in the empirical section of this paper, such practices are always implicated within structures of power, inequality and, in the case of Newham, socio-economic disadvantage.

Practices of convivial labour are often enacted when attempting to cross symbolic boundaries. Although much contested ever since Barth's original work (Barth, 1969), especially regarding ethnic boundary making (Brubaker, 2004), concepts of boundary making are a useful approach to analyse more generally processes of social inclusion and exclusion (Wimmer, 2004, 2013). In regards to convivial relations, especially the notion of symbolic boundaries is useful, defined as 'conceptual distinctions made by social actors to categorize objects, people, practices, and even time and space' (Lamont \&Molnár, 2002:168). According to Wimmer (2013), boundary making approaches allow us to examine processes of both social closure as well as social opening. For example, regarding different waves of immigration, work on 'boundary shifting' has shown how migrants of Italian and Irish background in the US were originally not 'white enough' to be accepted into the Protestant majority, but by distancing themselves from African Americans, managed to 'become white' and be accepted into the 'mainstream' (Foner, 2000). The dominated thus 'sometimes strategically and successfully adopt cultural boundary markers in order to disidentify with other minorities or their own ethnic category and gain acceptance by the majority' (Wimmer 2013:31).

Especially work on symbolic boundaries has demonstrated how moral discourses of civility and order are often used to draw boundaries between groups, and how such boundaries can shift according to context, situation and time (Albeda et al. 2018; Lamont \& Molnár, 2002; Wimmer, 2004). For example, Wallman (1982) has shown how in a South London area the distinction between 'us' and 'them' is based on the observance of rules of rubbish disposal, local investment in associations and length of residence, rather than along lines of ethnicity and race (see also Erel 2011; Wimmer 2004).More recently, Charsley and Bolognani (2017) have shown how British Pakistanis construct cultural boundaries towards Pakistani newcomers by drawing on notions of respectability (see also Elias \& Scotson 1994; Skeggs 1997).In the empirical part of this article, I will show how 
these discourses of moral order are an integral part of social relations with those perceived as 'different' or 'other', and how the breaking of what long-term residents see as 'civility' can lead to the 'othering' of those who are seen to break public order. Furthermore, convivial labour is used both to counter racism, as well as to build connections with newcomers who are perceived as different.

\section{The research}

Newham in East London, with its total population of 307,984 , is a classical migrant reception area, where new arrivals find their feet. In 2015, only $44 \%$ of Newham's population had been living in the area for more than ten years, while $37 \%$ had lived in the area for less than five years (London Borough of Newham, 2016).

At the time of the 2011 census, $35.7 \%$ of Newham's population were of south Asian backgrounds, originating in India, Bangladesh, Pakistan and Sri Lanka, while $16.7 \%$ identified as white British, $12.3 \%$ as Black African, $11.4 \%$ as white other, $6.5 \%$ as other Asian, $5 \%$ as 'mixed' and 4.9\% as Caribbean (Aston-Mansfield, 2017; London Borough of Newham, 2011). While the overall ethnic profile has not significantly changed since the census, the ethnic profile of more recently arrived residents has shifted, with a high number being of 'white other' backgrounds, originating mainly in Poland, Lithuania and Romania. Since EU accession in 2004, the number of Eastern European residents in Newham has reached an average of $8 \%$ (Aston-Mansfield, 2017). These newcomers are not only differentiated in terms of countries of origin but also regarding educational backgrounds, socio-economic status and other such factors.

Importantly, Newham has also seen an increase in migrants of other backgrounds, for example from Italy and Spain (with many of these migrants originating in Latin America, Africa and Bangladesh), Africa and Latin America (Aston-Mansfield, 2017). However, when asking longestablished residents about changes in Newham's population, it is Eastern Europeans which people 
refer to. This is partly due to their visibility in public spaces such as squares and parks, as well as an increasing number of Eastern European shops, restaurants and cafes.

Despite some areas of Newham being only a stone's throw away from London's Canary Wharf with its international banks and businesses, the area is one of the most deprived areas in the UK, with unemployment at $8.6 \%$ and the highest child poverty rate in London (41\%) (New Policy Institute, 2015). Those with limited English skills are particularly affected by poverty, and residents of ethnic minority background live in households with lower net income than those of a white background (London Borough of Newham, 2016).

The material presented in this paper draws on 15 months of ethnographic fieldwork in Newham, starting in February 2018. The project engaged with both long-established residents and newcomers. The fieldwork consisted of participant observation in weekly community groups such as a knitting group and coffee mornings at community centres. It included observations in public and semi-public spaces such as markets, libraries, shops and street corners, countless informal conversations with local residents and in-depth interviews. At the time of writing this article, a total of 120 respondents had participated in the research, consisting of 22interviews with residents of ethnic minority background and migrants, ten expert interviews with key people such as policemen and women, social workers, teachers, and religious leaders, and eight focus group interviews with residents of different generations such as teenagers, parents and grandparents. Research participants represent a cross section of first-generation migrants, their children and grandchildren as well as newcomers. Research participants were from a wide range of backgrounds. The longerterm residents originate in South Asia (including south Asians from East Africa), the Caribbean, Africa and the UK. While most research participants of South Asian origin are Muslim, some research participants are of Hindu or Sikh backgrounds. More recent migrants included people from Eastern European countries such as Poland and Lithuania, Italians of Bangladeshi origin, Moroccans (some of whom migrated via Spain), and Latin Americans. The sample is thus diverse in terms of ethnicity, religion, generation, age and ethnicity. The research participants represented in this article share 
their long-term residence in Newham (either all their lives or 20+ years) and relative deprivation, with the majority being on lower incomes or on benefits, and only three respondents having a university degree. The sample consisted of a majority of women, as only few men participated in the community groups. This is also related to issues around easier access to women as a female researcher. Access was gained through key people such as teachers, librarians and social workers with whom I established relationships of trust. Thanks to the help of these gatekeepers, most residents willingly participated in interviews and focus groups as they were interested in talking about population changes in the area.

Interviews and focus groups were transcribed, and transcriptions and fieldwork notes were coded in NVivo to identify the key issues raised by respondents. Ethical approval was gained in advance of fieldwork being undertaken and full written consent was received from all interviewees. Research participants quoted in this article could choose to change their names.

\section{Experiences of racism as backdrop to reactions to newcomers}

How do experiences of exclusion affect attitudes towards newcomers? How did ethnic minority research participants relate their own history of immigration and exclusion to the settlement of more recent migrants? This section first presents some examples of experiences of racism of ethnic minority residents, before moving on to their reactions to newcomers. I will highlight how white British residents constructed symbolic boundaries through discourses around 'territorial take over' and the lack of English being spoken in the area. In the subsequent section, I show how these symbolic boundaries were replicated by ethnic minority research participants in their discourses about Eastern European newcomers. However, their views were complicated by their literacy and attentiveness to racism, reflecting on newcomers' struggles of settling through the lens of their own and their parents' experiences of exclusion. 
Most research participants who had either come to Newham some thirty or more years ago or had grown up in the area described most parts of Newham as fairly safe where experiences of racism were rare in contrast to other areas in London and the UK. Questions about racism were usually answered by stating that things were either worse in the past, or elsewhere. Especially elderly research participants who had moved to the UK from the 1950s onwards had strong memories of 'everyday racism' (Essed 1991). This also included members of the second generation who grew up in the 1970s and remember, for example, having bricks thrown at them (see also James 2015; 2016).

This aggressive everyday racism was reported to have decreased over time. When speaking to younger people (teenagers and people in their twenties), they reported few experiences of everyday racism within the areas in Newham where they lived. But they felt very differently when going to more white British areas of Newham and especially outside of London. Furthermore, worries about continuities of institutionalized racism were expressed by all age groups, especially in regards to finding jobs and Stop and Search activities by the police (James 2016; Miller 2010). Many Muslim research participants clearly felt that Islamophobia increased considerably since $9 / 11$. This has been shown in various studies looking at Islamophobia in Britain and beyond (Allen, 2010; Hoque, 2015; Sheridan, 2006). Kay, a British Asian Muslim woman who was born and bred in Newham described how she grew up in the 70s when she did experience racism in the streets, but how things got better in the course of the 80 s and especially the 90s. And then things deteriorated again after 2001. Like other female Muslim research participants, she has since developed specific strategies to maintain and create peaceful relations with people who might have negative views about Muslims. One such strategy relates to how she presents herself in public space and how she speaks, as exemplified in the following quote:

You know car boot sales? The best ones are on farms, like Essex have a lot of them. And I love going there. So when we went up to these, I would make sure I wore a light-coloured head scarf because I found that when I wore all black, the 
English were very hostile there. That's when I was going to encounter a lot of English from a closed community if you like.

We used to call it my "Essex hijab" because it was white. So I'd go in my Essex hijab just to lighten the mood a little bit. When they could see I could speak English, with a cockney accent, that was their first shock. (...) I once got in the way of someone with my trolley, and the guy said something like "oh run me over, why don't you?" And so I turn around very politely and say, "oh did I nearly knock you out there, I'm really sorry!" He was just taken aback "no, love, that's okay, no worries, you carry on" and I turned around and thought, "hmm, you thought I didn't speak English" and then when I come through with a cockney accent, it's a different story.

This anecdote shows how Kay is highly aware of being subject to Islamophobia due to her headscarf and especially within ethnically less diverse places. She responds to previous experiences of Islamophobia by using her 'Essex hijab', and thus attempting to minimize her visible difference. At the same time, she actively demands recognition and reciprocity by speaking to the perpetrator in her Cockney accent, demonstrating her belonging and right to be here. She thereby engages in convivial labour to cross the symbolic boundary created by the racist perpetrator, using language to affirm her belonging (see also Lamont et al. 2016; Goffman 1971).

Another example of everyday racism where language, but also claims to territorial ownership were pertinent took place during a coffee morning in a community centre where mostly elderly people of various backgrounds came together. On this day, there were about eight people of different ethnic minority backgrounds (Caribbean, India, Philippines, Malaysia) and about four white British people who had grown up in Newham. The coffee morning was run by a British Muslim woman who knew most of the coffee drinkers and had very friendly relations with them, including the white British people. The coffee drinkers were happy to talk to me about living in Newham. When asked about changes to the area, however, it was the white British residents who dominated 
the conversation. They complained about how 'the Muslims' had taken over the area, that every free space was turned into a mosque, and that the area had become 'the league of nations'. None of the other coffee drinkers reacted to this, including the British Muslim woman running the group. Later, however, I found out that she and the others were unhappy about this exchange but did not want to cause tensions by reacting to these remarks. This situation repeated itself at the next two coffee mornings which were run by a social worker of African origin. For example, white British coffee drinkers complained about how none of their neighbours spoke English. They said this despite the fact that they were surrounded by coffee drinkers of ethnic minority background who all spoke perfect English. Again, these statements were met with silence by the ethnic minority participants. When I asked the social worker about these incidents later on, he emphasized that rather than causing open conflict in the group, he felt it was wiser to ignore these remarks and move on in the conversations. Further conversations with a retired participant of Caribbean background revealed much bitterness about these incidents, coupled with a certain hopelessness that things will not change. She recounted that having worked in the health sector as a nurse, she is used to this kind of abuse. But she also wondered whether it was worth continuing to attend the coffee morning. How do these experiences impact on reactions to newcomers, especially people from Eastern Europe who, due to their whiteness, might be seen to have it easier when settling in the UK? The following section reflects on ethnic minority members' reactions to newcomers and how the symbolic boundaries created towards the newcomers are expressed along similar lines as those created by white British people against ethnic minorities, namely language, spatial 'take over' and notions of civility and order. Importantly, however, and in contrast to the white British coffee drinkers, their views were more nuanced in that their own experiences of exclusion always formed the backdrop to perceptions about newcomers and thus relativized potential negative views.

\section{Reactions towards newcomers and new forms of conviviality}


When asked about changes to the area in which they lived, all research participants mentioned Eastern European immigration as one of the most noticeable changes. Rather than seeing these newcomers as part of the many other newcomers from various places in the world, they were seen to stick out and not blend into Newham's diversity. One of the reasons for this were views that these newcomers were not interested in mixing with the rest of the population. For example, a group of ethnic minority mothers at a primary school expressed their disappointment about Eastern European parents' limited effort to interact with them at the school gates. They felt that it was left up to them to take the initiative to interact, and that it was not a mutual process (see also Wessendorf 2013). They also expressed a sense of exclusion when hearing Eastern Europeans speak in their own language in public space. In their view, not speaking English conferred the message that these newcomers did not want to interact with them. The following quote from a focus group with mothers of ethnic minority background (all British Muslims except Sharon who is of Caribbean backgroundi) captures these feelings:

Sharon: You go to East Ham and they've got their cafés, they take over the whole cafés, where's that interacting or anything like that, it's separation isn't it, they've got two cafés, one at that side of the road and the other on that side, and it's just them! What about everybody else! Can't we sit in your café? Fatima: Well you don't feel like you can sit there do you, no you don't. Sharon: It's just them! Jamilah: It's hard to walk in anywhere where someone, when everyone is talking a different language to you.

Fatima: When we came, we opened up Indian restaurants, it was open for ALL Sharon: It was for everybody.

Fatima: It was for everyone, and everyone could come in. 
Jamilah: But then everyone who was working and everything was speaking English half of the time, unless there was something at the back, but if you walk into a place, and everyone is talking in a foreign language, you're going to feel isolated, you won't want to go in, that's the whole issue, and that's a way of saying 'we don't want you here'.

Ayshe: I think it's just like with every community, as I say London is like a melting pot for every culture, and it's nice, but at the same time, what the government don't see is that segregation that happens individually, and sometime, you know to bring people together, you need to put stuff out there so people can enjoy and do stuff.

By talking about the newcomers' perceived refusal to speak English, these women touch on the notion of 'not wanting to mix'. They contrast this with their own history of immigration and emphasise that they always showed openness to mix. Although their parents did not speak much English, according to them, they instilled in their children to speak English in public space. Interestingly, the criticism that the newcomers do not want to mix is exactly what many British Muslims are criticised for both in public and policy discourse (Cantle, 2001; Casey, 2016). Resonating with James' (2015) findings among ethnic minority youth in Newham, the mothers also make territorial claims to the area ('we were here first'), expressing their frustration about newcomers opening cafés and 'taking over' the area. Just like the issue of newcomers not speaking English, this criticism represents the same discourse of exclusion which they themselves, their parents and their children have been and continue to be subject to in public and policy discourse, exemplified in the previous section with the example of the coffee morning.

While these mothers create a symbolic boundary to the newcomers on the basis of the newcomers' perceived unwillingness to interact or speak English, they also bemoan the lack of opportunities to mix by blaming 'the government' for not providing such opportunities. In the 
ensuing discussion, they highly praised a social work programme in the school which brought different parents together, for example in cooking classes. Not only did this programme provide opportunities to do something out of the everyday, but the mothers also formed social relations with other mothers whom they would not have met otherwise, including Eastern Europeans. They expressed the wish for more such opportunities for convivial relations, showing their readiness to cross the symbolic boundaries they had formed in reaction to the fleeting and unsatisfactory interactions at the school gates and to invest in convivial labour (see also Vincent et al. 2018).

Their views are also shaped by encounters in public spaces such as parks and street corners. One of the repeated criticisms about Eastern Europeans was that they drink in public space, something that especially Muslim residents find difficult to accept. There was also much criticism of increased begging on the streets which was ascribed to Romanians. For my research participants, both drinking in public space and begging break rules of civility and conviviality, an issue that has also arisen in other UK contexts regarding Eastern European migrants (Pemberton, 2017). These views, however, were also shaped by resentment related to their own experiences of racism as well as competition over resources. For example, one of my research participants expressed her frustration that 'they don't even speak English but they get the jobs because they are white'. When asked whether they thought that Eastern Europeans have it easier than their parents or grandparents when first arriving, the group of mothers responded with a rather heated discussion:

Sharon: They take over everything

Jamilah: But this is it like, we sit here and we're like, a lot of Eastern Europeans when they first came they were just like our parents when they first came.

Sofia: Yes, I was going to say that yes.

Jamilah: It's like they are facing the exact same...

Fatima: But really not really. It's not as bad as it was, plus...

Sharon: I'm not being funny but the white skin... 
Fatima: thank you.

Sharon: Being white you got it easier. You go into Tesco and take all the top bloody jobs, and we're made to be looking low, I've been there for like over 20 years but they've come over and take all the bloody jobs. It's all the colour of the skin, isn't it?

Fatima: If Anna [white British teacher] was at the [school] gate and there was an Eastern European, you don't see the difference, only if they spoke, then sometimes, because they have blond hair, brown hair, they are very similar, only when they speak, maybe they have an accent or they speak in their language, that you know that they are from... Whereas with us, even if we have a scarf or don't, you can tell.

Sharon: We're still different

Jamilah: But what I'm saying is that they still have, not all the same issues that we had when we first came...

Sharon: But they work for cheaper as well apparently, they work for cheaper. Jamilah: But then they still have the same issues.

This discussion illustrates the mixed feelings these women have about the newcomers. Importantly, the negative views have to be placed in a context of precarity. Sharon, for example, a mother of four children, is worried about her children's future as well as their safety when out and about in public space. With an increase in knife crime in the area, as well as the closing down of youth services, her and her children's lives are characterised by increased precarity (see also Mintchev \& Moore 2016). This precarity is also shaped by the fear of losing her job in a large supermarket due to increased competition.

Despite the resentment about the newcomers and the view that they have it easier because of the colour of their skin, the discussion also shows empathy towards the newcomers and how 
histories of migration and the struggles of their parents' settlement have not been forgotten. They also acknowledged that in the aftermath of the Brexit vote, Eastern Europeans had their own struggles of exclusion.

While their views wavered between empathy and resentment, the mothers as well as other research participants described interactions on the ground as similarly nuanced. For example, those mothers whose children made Eastern European friends in school acknowledged that they did sometimes exchange smiles with these children's mothers. An elderly woman in the knitting group whose neighbours are Eastern European praised them for letting her know when they had a BBQ so that she could take her washing in. At the same time, she was disgruntled about Eastern European drinkers in the local park who are leaving their empty cans next to park benches. These examples demonstrate how, as stated by Wise and Noble (2016), attitudes and stereotypes are shaped by practices of conviviality and interaction. Importantly, and as exemplified with the example of Sharon, they also have to be interpreted in the context of individuals' histories of exclusion and their current socio-economic positions.

\section{Conclusion}

Literature on conviviality has addressed how people live together in the context of increasing societal complexity. Scholars have particularly pointed to the labour involved in maintaining convivial relations (Nobel 2009; Wise 2016). This labour becomes particularly pronounced regarding negotiations of symbolic boundaries with others perceived as different. This article has brought concepts of boundary making and conviviality together to shed light on long-established ethnic minorities' attitudes, encounters and social relations with Easter European newcomers in East London. It has situated this within their own histories of exclusion and racism, and their ongoing socio-economic precarity in one of the poorest areas in Britain and during times of austerity.

Ethnic minorities in East London have experienced several decades of exclusion along racial and religious lines. Among the most prominent discourses of exclusion are those that claim that 
immigrants 'take over an area', do not speak English and do not want to mix. The participants of the research presented in this article have developed various strategies to deal with these experiences and discourses. Some attempt to cross symbolic boundaries by asserting their belonging, for example via speaking the majority language or local dialect. They actively invest in convivial labour in order to break stereotypes and confront racism. Others ignore stigmatization because countering it is perceived as pointless, especially in light of repeated and ongoing experiences of racism and Islamophobia (see also Lamont at al. 2016; Hargreaves 2016).

How are these experiences of stigmatization related to attitudes towards newcomers? When talking about Eastern European newcomers, research participants drew on similar discourses of exclusion which they and their parents had been subjected to, namely notions around territorial take over, not speaking English and not wanting to mix. These were also tied to notions of respectability. They emphasized how historically, they and their parents attempted to fit in, for example by way of speaking English in public space and their willingness to mix. They contrasted this with newcomers' perceived refusal to speak English and their unwillingness to mix, replicating criticisms in public and policy discourse aimed at their own 'communities' for leading 'parallel lives' (Cantle, 2001; Casey, 2016).

Symbolic boundaries were also formed by drawing on discourses of moral order and civility (Wimmer, 2004, Skeggs 1997) on the bases of what was perceived to be inappropriate behavior among the newcomers in public space, such as drinking and begging. This echoes with other work on symbolic boundary making which has shown how the reproduction of stigma serves to gain 'relative status in hierarchies of belonging' (Charsley and Bolognani 2017:50; see also Wimmer 2013).i It also confirms that migrant and ethnic minority populations are not immune to xenophobia (Binder 2012). Importantly, these boundaries were formed in a context of socio-economic precarity. Fears of losing one's job or being unable to secure a successful future for their children due to structural racism formed the backdrop to these sentiments. Competition over jobs was directly related to the newcomers' whiteness, which was seen as putting the newcomers in an advantaged position. 
However, these boundary making processes were accompanied by forms of solidarity by way of empathizing with the hardship of initial settlement and the newcomers' struggles in the context of a hostile environment in the aftermath of the Brexit vote. This solidarity was also expressed in a wish for more opportunities to interact and meet the newcomers in settings which go beyond encounters in public space, but in spaces where more sustained and regular interactions can take place (see also Amin 2005). This wish is another example of the willingness to engage in convivial labour.

To date, little is known about the social dynamics of encounter and interaction in contexts of ongoing and diversified immigration and newly emerging forms of both inclusion and exclusion (but see Albeda et al. 2018; Erel 2011, Hickman, Mai \& Crowley 2012). Debates on migrant settlement often overlook the fact that newcomers tend to settle in areas characterized by long-term immigration, and that historical and ongoing experiences of Islamophobia and racism among the long-term settled ethnic minorities might impact on the reception of newcomers. Furthermore, longterm socio-economic conditions affecting ethnic minorities (including limited social mobility and ongoing institutionalized racism) shape patterns of conviviality. This article has demonstrated the combination of both resentment towards white newcomers and worries about competition over jobs, as well as investment in convivial labour. While much of the current policy discourse on cohesion in the UK continues to primarily focus on the need to bridge 'parallel lives' and make people interact (HM Government, 2018), the findings demonstrate that tackling ongoing Islamophobia and racism as well as deprivation should be an integral part of investing in 'cohesive communities'.

\section{References}

Albeda, Y., Tersteeg, A., Oosterlynck, S., \&Verschraegen, G. 2018. Symbolic Boundary making in Super-diverse Deprived Neighbourhoods. Tijdschrift voo rEconomischeen Sociale Geografie, 109(4), 470-484. 
Allen, C. 2010 Islamophobia, Farnham: Ashgate.

Amin, A. 2005 'Local Community on Trial', Economy and Society 34 (4): 612-633.

Aston-Mansfield Community Involvement Unit. 2017 Newham Key Statistics 2017, London: Aston Mansfield.

Barth, F. 1969 Ethnic Groups and Boundaries: the Social Organization of Culture Difference, Boston: Little Brown.

Binder, S. 2012 Briefing: UK Public Opinion towards Immigration, Oxford: The Migration

Observatory.

Blokland, T. 2003 Urban Bonds, Cambridge: Polity.

Brubaker, R. 2004 Ethnicity without Groups, Harvard: Harvard University Press.

Butler, T. and Hamnett, C. 2011 Ethnicity, class and aspiration: Understanding London's new East End, Bristol: The Policy Press.

Cantle, T. 2001 Community Cohesion. A report of the Independent Review Team, London: Home Office.

Casey, L. 2016 The Casey Review. A review into opportunity and integration, London: Department for Communities and Local Government.

Charsley, K. and Bolognani, M. 2017 'Being a freshie is (not) cool: stigma, capital and disgust in British Pakistani stereotypes of new subcontinental migrants', Ethnic and Racial Studies 40(1): 43-62. Cole, M. 2009 'A Plethora of 'suitable enemies': British racism at the dawn of the twenty-first century', Ethnic and Racial Studies 32(9): 1671-1685.

Dench, G., Gavron, K. and Young, M.D. 2006 The new East End: kinship, race and conflict, London: Profile Books Ltd.

Elias, N., \& Scotson, J. L. 1994. The Established and the Outsiders: a Sociological Enquiry into Community Problems. London: Sage.

Erel, U. 2011 'Complex belongings: Racialization and migration in a small English city', Ethnic and Racial Studies 34(12): 2048-2068. 
Essed, P. 1991 Understanding everyday racism: an interdisciplinary theory, London: Sage.

Foner, N. 2000 From Ellis Island to JFK : New York's Two Great Waves of Immigration, New Haven; London: Yale University Press; Russell Sage Foundation.

Fox, J. E., Morosanu, L. and Szilassy, E. 2012 'The Racialization of the New European Migration to the UK', Sociology 46(4): 680-695.

Fox, J. E. and Mogilnicka, M. 2017 'Pathological integration, or, how East Europeans use racism to become British', The British Journal of Sociology 70(1): 5-23.

Gilroy, P. 2004 After empire: melancholia or convivial culture?, London: Routledge.

Goffman, E. 1971 The presentation of self in everyday life, London: Penguin.

Hall, S. 2012. City, street and citizen: the measure of the ordinary. London: Routledge.

Hargreaves, J. 2016 'Risk and resilience in British Muslim communities', Ethnic \& Racial Studies 39(14): 2601-2620.

Heil, T. 2014. Are neighbours alike? Practices of conviviality in Catalonia and Casamance. European Journal of Cultural Studies, 17(4), 452-470.

Hewitt, R. 2005 White backlash and the politics of multiculturalism, Cambridge: Cambridge University Press.

Hickman, M., Mai, N. and Crowley, H. 2012 Migration and Social Cohesion in the UK, Basingstoke: Palgrave Macmillan.

HM Government. 2018 Integrated Communities Strategy Green Paper, London: Ministry of Housing, Communities and Local Government.

Hoque, A. 2015 British-Islamic identity: third-generation Bangladeshis from east London, London: IOE Press.

James, M. 2015 Urban multiculture: youth, politics and cultural transformation in a global city, Basingstoke: Palgrave Macmillan. 
James, M. 2016 Brexit London: the past, present and future of racism in the capital, The Sociological Review Blog. https://www.thesociologicalreview.com/blog/brexit-london-the-past-present-and-

future-of-racism-in-the-capital-1.html [accessed 2. April 2019].

Karner, C. and Parker, D. 2011 'Conviviality and Conflict: Pluralism, Resilience and Hope in Inner-City Birmingham', Journal of Ethnic and Migration Studies 37(3): 355-372.

Lamont, M. and Molnár, V. 2002 'The Study of Boundaries in the Social Sciences', Annual Review of Sociology 28: 167-195.

Lamont, M. 2016 Getting respect: responding to stigma and discrimination in the United States, Brazil, and Israel, Princeton: Princeton University Press.

Lee, J. 2002 Civility in the city: Blacks, Jews, and Koreans in urban America, Cambridge, Mass.: Harvard University Press.

London Borough of Newham. 2011 Newham Key Statistics based on Mayhew Data, London Borough of Newham.

London Borough of Newham. 2016 Understanding Newham 2015. Findings from Wave 8 of the Newham Household Panel Surveys, London: Ipsos MORI Social Research Institute.

Miller, J. 2010 'Stop and Search in England: A Reformed Tactic or Business as Usual?', The British Journal of Criminology 50(5): 954-974.

Mintchev, N. and Moore, H.L. 2016 'Community and Prosperity beyond social capital: The case of Newham, East London', Critical Social Policy 37(3): 1-20.

Neal, S., Bennet, K., Cochrane, A. and Mohan, G. 2013 'Living multiculture: understanding the new spatial and social relations of ethnicity and multiculture in England', Environment and Planning C 31: 308-323.

Neal, S., Vincent, C. and Iqbal, H. 2016 'Extended Encounters in Primary School Worlds: Shared Social Resource, Connective Spaces and Sustained Conviviality in Socially and Ethnically Complex Urban Geographies', Journal of Intercultural Studies 37(5): 464-480.

New Policy Institute. 2015 London's Poverty Profile, Newham. 
Noble, G. 2009 'Everyday Cosmopolitanism and the Labour of Intercultural Community' in A. Wise and S. Velayutham (eds) Everyday multiculturalism. Basingstoke: Palgrave Macmillan, pp. 47-67. Noble, G. 2011 'Belonging in Bennelong: ironic inclusion and cosmopolitan joy in John Howard's (former) electorate, in K. Jacobs and J. Malpas (eds) Ocean to Outback: Cosmopolitanism in contemporary Australia. Crwaley: UWA Press, pp. 150-174.

Pemberton, S. and Phillimore, J. 2016 'Migrant place-making in superdiverse neighbourhoods: moving beyond ethno-national boundaries', Urban Studies 55(4): 733-750

Pemberton, S. 2017 The importance of super-diverse places in shaping residential mobility patterns. A Report to the Leverhulme Trust, Keele: Keele University.

Phillimore, J., Humphris, R. and Khan, K. 2014 Migration, networks and resources: the relationship between migrants' social networks and their access to integration resources. KING Project - Applied Social Studies Unit.

Phillips, D., Athwal, B., Robinson, D., \& Harrison, M. 2014. Towards Intercultural Engagement: Building Shared Visions of Nehgbourhood and Community in an Era of New Migration. Journal of Ethnic and Migration Studies, 40(1), 42-59.

Ray, K., Hudson, M. and Phillips, J. 2008 'Belonging and entitlement: Shifting discourses of difference in multiethnic neighbourhoods in the UK' in K. Tyler and B. Petterson (eds) Majority Cultures and the Practices of Ethnic Difference: Whose House is this?, Basingstoke: Palgrave, pp. $114-135$.

Robinson, D. and Reeve, K. 2006 Neighbourhood experiences of new immigration: Reflections from the evidence base, London: Joseph Rowntree Foundation.

Sandercock, L. 2003 Cosmopolis II: mongrel cities of the 21st century, London: Continuum. Sheridan, L.P. 2006 'Islamophobia Pre- and Post-September 11th, 2001', Journal of Interpersonal Violence 21(3): 317-336.

Skeggs, B. 1997 Formations of class and gender: becoming respectable, London: Sage. 
Tyler, K. 2016 'The suburban paradox of conviviality and racism in postcolonial Britain', Journal of Ethnic and Migration Studies 43(11): 1890-1906.

Valentine, G. 2013 'Living with difference: Proximity and encounter in urban life', Geography 98 (1): 4-9.

Vertovec, S. 2007 'Super-diversity and its implications', Ethnic and Racial Studies 30(6): 1024-1054.

Vertovec, S. and Wessendorf, S. (eds). 2010 The Multiculturalism Backlash. European Discourses, Policies and Practices, London; New York: Routledge.

Vertovec, S. (ed). 2015 Diversities Old and New. Migration and Socio-Spatial Patterns in New York, Singapore and Johannesburg, London: Palgrave Macmillan.

Vincent, C., Neal, S. and Iqbal, H. 2018 Friendship and Diversity. Class, Ethnicity and Social Relationships in the City, Basingstoke: Palgrave Macmillan.

Wallman, S. 1982 Living in South London, Aldershot: Gower.

Wessendorf, S. 2013 'Commonplace Diversity and the 'Ethos of mixing': perceptions of Difference in a London Neighbourhood', Identities. Global Studies in Culture and Power 20(4): 407-422.

Wessendorf, S. 2014 Commonplace Diversity. Social Relations in a Super-diverse Context, Basingstoke: Palgrave Macmillan.

Wimmer, A. 2004 'Does Ethnicity Matter? Everyday Group Formation in Three Swiss Immigrant Neighbourhoods', Ethnic and Racial Studies 27(1): 1-36.

Wimmer, A. 2013 Ethnic boundary making: institutions, power, networks, Oxford: Oxford University Press.

Wise, A. 2009 'Everyday Multiculturalism: Transversal Crossings and Working Class Cosmopolitans' in A. Wise and S. Velayutham (eds) Everyday Multiculturalism, Basingstoke: Palgrave Macmillan, pp. 21-45

Wise, A. 2016 'Convivial Labour and the 'Joking Relationship': Humour and Everyday Multiculturalism at Work', Journal of Intercultural Studies 37(5): 481-500. 
Wise, A. and Noble, G. 2016 'Convivialities: An Orientation', Journal of Intercultural Studies 37(5):

423-431.

Wise, A. and Velayutham, S. 2014 'Conviviality in everyday multiculturalism: Some brief

comparisons between Singapore and Sydney', European Journal of Cultural Studies 17(4): 406-430.

\footnotetext{
' Eight mothers participated in the focus group, six of whom were born in the UK. One was of Caribbean background, two of Somali origin and four of Bangladeshi background. They were aged 25 to 40 .

ii See also Fox and Mogilnicka who describe how Eastern Europeans in the UK 'learn to be racist' as a means of integration and to attenuate the status degradations which they suffered when coming to the UK.
} 